\title{
Isolation and selection of highly effective phosphate solubilizing bacterial strains to promote wheat growth in Egyptian calcareous soils
}

Abdallah E. Mohamed ${ }^{1}$, Maher Georg Nessim², Islam Ibrahim Abou-el-seoud ${ }^{2}$, Khaled Mohamed Darwish ${ }^{*}$ (D) and Abdelaal Shamseldin ${ }^{3}$

\begin{abstract}
Background: Forty phosphate solubilizing bacterial (PSB) isolates were isolated from the root zone of wheat plants cultivated in the Delta and the Northwestern coast regions of Egypt. All isolates proofed their ability to dissolve tricalcium phosphate on the National Botanical Research Institute's phosphate growth medium (NBRIP) by producing clear zone and increasing the available phosphorus that ranged between 40 and $707 \mathrm{mg} \mathrm{I}^{-1}$. They were designated as Egyptian native phosphate solubilizing bacteria (ENPSB).

Results: All strains proofed their ability to dissolve tricalcium phosphate on (NBRIP) medium by producing clear zone and increasing the available phosphorus that ranged between 40 and $707 \mathrm{mg} \mathrm{I}^{-1}$. The ENPSB 1, 2, and 3 strains were highly efficient as they gave 707,653, and $693 \mathrm{mg} \mathrm{I}^{-1}$ soluble phosphorus respectively. Intriguingly, the two highly efficient strains for phosphate solubilization were isolated from the Northwestern coast alkaline soils. Moreover, $75 \%$ of strains were also produced profitable amounts of indole acetic acid (IAA) ranged from 0.79 to $50.5 \mathrm{mg} \mathrm{I}^{-1}$. Amazingly, the most efficient strain ENPSB 1 in solubilizing phosphorus ( $707 \mathrm{mg} \mathrm{I}^{-1}$ soluble P) was the best one for producing IAA $\left(50.5 \mathrm{mg} \mathrm{I}^{-1}\right)$. The three efficient strains were identified using the sequencing of $16 \mathrm{~S} r R N A$. Sequence analysis of 165 rRNA for selected strains confirmed that the strains ENPSB 1, 2, and 3 were genetically closed to Enterobacter aerogenes; Pantoea sp. and Enteriobacter sp. respectively.
\end{abstract}

Conclusion: The inoculation by mix cultures of strains (ENPSB 1,2, and 3) contributed to raising the dry weight and P content of wheat plants by $76 \%$ and $12 \%$ over the full fertilized plants. Inoculation of soil PSB can be used to solve the deficiency of phosphorus and promote plant growth effectively in calcareous soils.

Keywords: Egyptian Calcareous soils, solubility of Phosphorus, Phosphate Solubilizing Bacteria PSB, Indole acetic acid IAA

\section{Introduction}

Phosphorus (P) is an essential element for plant growth and production. Nitrogen $\mathrm{N}_{2}$ fixation in legumes, crop quality, and resistance to plant diseases are some of the important attributes associated with $\mathrm{P}$ nutrition. It is a major limiting factor for plant growth due to its low availability for root uptake when it presents as rock phosphate.

\footnotetext{
* Correspondence: kdarwish@hotmail.com; kdarwish@srtacity.sci.eg 'Land and Water Technologies Department, Arid Lands Cultivation Research Institute (ALCRI), City of Scientific Research and Technological Applications (SRTA-City), Borg El-Arab, Alexandria, Egypt

Full list of author information is available at the end of the article
}

Therefore, it becomes quite common to use chemical fertilizers in ensuring phosphorous requirements to soil. Upon application as inorganic, phosphorus is rapidly transformed into less available forms by forming a complex with (Ca) in calcareous soils (Toro 2007). On the other hand, frequent application of chemical fertilizers is associated with environmental problems.

Due to health and environmental hazards resulted from excessive application of chemical fertilizers, researchers are doing great efforts to find another alternative strategy that can ensure competitive yields and keep soil health. 
This new approach called sustainable agriculture which is safety to the environment and it keeps balance in the soil ecosystem for the long-term. In this context, the use of microbial inoculants which including phosphate solubilizing microorganisms (PSM) in agriculture represents a friendly alternative environment method compared to mineral fertilizers (Khan et al. 2007). The microbial solubilization of soil phosphorus in liquid medium has often been due to the excretion of organic acids. Organic acids produced by PSB release soluble phosphate through lowering of $\mathrm{pH}$, chelating of cations and by competing with phosphate for adsorption sites in soil (Nahas 1996).

Phosphate solubilizing bacteria (PSB) can provide the available forms of $\mathrm{P}$ to the plants and hence a viable substitute to chemical phosphate fertilizers (Khan et al. 2006). Bacterial genera like Azotobacter, Azospirillum, Bacillus, Beijerinckia, Burkholderia, Enterobacter, Erwinia, Flavobacterium, Microbacterium, Pseudomonas, Rhizobium, and Serratia are reported as the most significant phosphate solubilizing bacteria (Sudhakar et al. 2000; Mehnaz and Lazarovits 2006; Bhattacharyya and Jha 2012). Many researchers have investigated the ability of PSB to solubilize insoluble phosphate in pure liquid culture medium (Narula et al. 2000).

Some strains of phosphate dissolving bacteria are considered IAA producers. Generally, IAA improves the state of plants in all stages of growth, due to increasing the amount of root exudates in the rhizosphere (Glick 2012).

The use of plant growth-promoting rhizobacteria (PGPR) including PSB as bio-fertilization is a well sustainable solution to improve plant growth, plant nutrition, root growth pattern, plant competitiveness, and tolerance to environmental stresses (Setiawati and Handayanto 2010; Ekin 2010). Using of biofertilizations in Egyptian soils has decreased soil $\mathrm{pH}$, leading to increase availability of elements and enhance plant growth (Mahfouz and Sharaf-Eldin 2007).

Several authors have been studied using PSB to enhance the growth of maize, wheat, and lettuce plants (Richardson 1994; Lifshitz et al. 1987). Inoculation with Pseudomonas putida (Lifshitz et al. 1987), Azospirillum lipoferum (Murty and Ladha 1988), Bacillus firmus (Datta et al. 1982), and Bacillus polymyxa (Gaur and Ostwal 1972) were reported to be effective for increasing the solubility of phosphorus in soil.

Accordingly, the main objectives of the current study were to (i) isolation and identification of high effective strains of phosphate solubilizing bacteria; (ii) examination the ability of these isolates to solubilize tricalcium phosphate in vitro and to produce indole acetic acid; and (iii) studying the effect of these efficient isolates on wheat growth and phosphorus uptake in calcareous soil. Also, the effect of these isolates and P fertilizer application on the inorganic $\mathrm{P}$ fractions in relation to available $P$ in soil was discussed.

\section{Materials and methods}

\section{Isolation of bacterial strains}

Soil samples were collected from the field of cultivated wheat in both Delta region and Northwestern Coast of Egypt. Collected moist soils were mixed with a sterile solution of $0.85 \% \mathrm{NaCl}$ and shacked for $30 \mathrm{~min}$. Serial dilutions were made and a aliquots of dilutions $\left(10^{-5}\right.$ and $10^{-6}$ ) were put on the surface of agar plates medium (National Botanical Research Institute Phosphorus, NBRIP) containing $\left(10 \mathrm{~g}\right.$ glucose, $5 \mathrm{~g} \mathrm{MgCl}_{2} \cdot 6 \mathrm{H}_{2} \mathrm{O}, 0.25 \mathrm{~g}$ $\mathrm{MgSO}_{4} .7 \mathrm{H}_{2} \mathrm{O}, 0.2 \mathrm{~g} \mathrm{KCl}, 0.1 \mathrm{~g}\left(\mathrm{NH}_{4}\right)_{2} \mathrm{SO}_{4}$, and $15 \mathrm{~g}$ Agar in $1 \mathrm{~L}$ distilled water) with $5 \mathrm{~g}$ tricalcium phosphate (TCP, $\left.\mathrm{Ca}_{3}\left(\mathrm{PO}_{4}\right)_{2}\right)$ as sole $\mathrm{P}$ source for selecting PSB isolates (Nautiyal 1999). The plates were incubated for 7 days at $30{ }^{\circ} \mathrm{C}$. The colonies with clear halos were considered to be phosphate solubilizing isolates and were further purified by re-streaking on the fresh NBRIP agar plates to obtain single colonies. These isolates (1-40) were designated as Egyptian native phosphate solubilizing bacteria (ENPSB). Phosphate solubilization index was calculated by inoculating the ENPSB onto NBRIP agar medium and measuring the diameter of halo zone and bacterial colony. The solubilization index [=the ratio of the total diameter (colony + halo zone) to the colony diameter] was calculated by formula of (Premono et al. 1996).

\section{Quantitative estimation of phosphate solubilization}

Quantitative estimation of phosphate solubilization in broth was carried out using Erlenmeyer flasks $(100 \mathrm{ml})$ containing $30 \mathrm{ml}$ of NBRIP medium inoculated in triplicate with the bacterial isolate $(0.3 \mathrm{ml}$ inoculum with approximately $10^{8} \mathrm{CFU} \mathrm{m}{ }^{-1}$ ), and autoclaved un-inoculated medium served as control. The flasks were incubated for 7 days at $30^{\circ} \mathrm{C}$ on incubator shaker at $150 \mathrm{rpm}$. The cultures were harvested by centrifugation at $10000 \mathrm{rpm}$ for $10 \mathrm{~min}$. Available phosphorous in the culture supernatant was estimated using (Olsen et al. 1954) method. Supernatant $\mathrm{pH}$ was measured using the glass electrode of digital $\mathrm{pH}$ meter. Among these isolates, ENPSB 1, ENPSB 2 and ENPSB 3 exhibited the highest P solubilization, were used for further studies. Culture suspension of these three isolates $\left(0.3 \mathrm{ml}\right.$ inoculum with approximately $10^{8}$ $\mathrm{cfu} \mathrm{ml}^{-1}$ ) were inoculated into triplicate $100 \mathrm{ml}$ flasks containing $30 \mathrm{ml}$ NBRIP broth and were incubated for 7 days on rotary shaker under aerobic conditions at $30{ }^{\circ} \mathrm{C}$ and $150 \mathrm{rpm}$. Uninoculated medium was used as control. Samples were withdrawn periodically at 1-day intervals for 7 days and analyzed to estimate phosphate solubilization in the culture supernatant.

\section{Estimation of IAA production}

To test whether the strains able to produce indole acetic acid (IAA) or not, the production of IAA was determined following the method by Brick (1991). After $48 \mathrm{~h}$ 
bacterial culture of an approximately $10^{8} \mathrm{cfu} \mathrm{m}^{-1}$ was inoculated into nutrient broth supplied with $3 \mathrm{mM}$ tryptophan and incubated at $30{ }^{\circ} \mathrm{C}$ for $48 \mathrm{~h}$. Bacterial cells were centrifuged at $3000 \mathrm{rpm}$ for $30 \mathrm{~min}$. Two milliliters of the supernatant were mixed with $100 \mu \mathrm{l}$ of orthophosphoric acid and $4 \mathrm{ml}$ of Solawaski's reagent $(12 \mathrm{~g}$ $\mathrm{l}^{-1} \mathrm{FeCl}_{3}+7.9 \mathrm{M} \mathrm{H}_{2} \mathrm{SO}_{4}$ ) and incubated at $37{ }^{\circ} \mathrm{C}$ for 30 min. The development of a pink color indicates IAA production, which was quantified using a spectrophotometer at $535 \mathrm{~nm}$. The concentrations of IAA produced by isolates were determined using a standard curve prepared from pure IAA from Sigma Company.

\section{DNA extraction and purification}

Extraction and purification of total genomic deoxyribonucleic acid (DNA) were carried out according to (Leonard et al. 1986). The three most efficient isolates were cultured routinely at $30{ }^{\circ} \mathrm{C}$ in nutrient broth medium. Total bacterial genomic DNA was extracted as follows: 5 $\mathrm{ml}$ of overnight bacterial culture was centrifuged for 10 $\mathrm{min}$ at $10000 \mathrm{rpm}$ (High-speed centrifuge Sorvall RC 285, USA) subsequently, pellets were re-suspended in $467 \mu \mathrm{l}$ lyses buffer containing $(30 \mu \mathrm{l}$ of $10 \%$ sodium dodicyl sulphate (SDS) and $3 \mu \mathrm{l}$ proteinase $\mathrm{K}$ from a stock of $20 \mathrm{mg} \mathrm{ml}^{-1}$ ), mixed well and incubated for one hour at $37^{\circ} \mathrm{C}$. The protein/DNA mixture was then subjected to phenol/chloroform extraction, and the upper aqueous phase was transferred to a new tube. An equal volume of absolute ethanol and 1/10 volume sodium acetate ( $\mathrm{pH}$ 5.2) were added for DNA precipitation, and then samples incubated at $-20{ }^{\circ} \mathrm{C}$ for $1 \mathrm{~h}$. After centrifugation, pellets of DNA were washed twice with $70 \%$ ethanol then air-dried, dissolved in $20 \mu \mathrm{l}$ sterile distilled water, and stored at $-20{ }^{\circ} \mathrm{C}$ until used.

\section{Sequence analysis of $16 S$ rRNA gene and phylogenetic tree}

$16 S$ rRNA gene sequencing involves amplification of target sequences using universal primers to yield about 1.5 $\mathrm{kb}$ amplicon followed by sequencing and homology generation using ribosomal DNA database. Polymerase chain reaction (PCR) was performed using (Eppenorff 9700 thermocycler) in a total volume of $50 \mu \mathrm{l}$. For each reaction the following reagents: $5 \mu \mathrm{l}$ buffer $10 \times, 4 \mu \mathrm{l}$ of $25 \mathrm{mM} \mathrm{MgCl} 2,1 \mu \mathrm{l}$ of $50 \mathrm{ng}$ Template DNA, $2 \mu \mathrm{l}$ of 10 pmol forward fD1 (5'-AGAGTTTGATCCTGGCTCAG$\left.3^{\prime}\right)$ and reverse rD1 (5' - AAGGAGGTGATCCAGCC-3') primers published by (Weisburg et al. 1991), $5 \mu$ l of 2.5 mM dNTPs, $0.4 \mu \mathrm{l}$ (5 units $\mu \mathrm{l}^{-1}$ ) of Taq Polymerase (Sigma), were added separately and de-ionized water was added to reach volume $50 \mu \mathrm{l}$, then the mixture was mixed well. The PCR cycling conditions consisted of: an initial de-naturation at $94{ }^{\circ} \mathrm{C}(5 \mathrm{~min}), 35$ cycles of denaturation at $94{ }^{\circ} \mathrm{C}(1 \mathrm{~min})$, annealing at $55{ }^{\circ} \mathrm{C}(1 \mathrm{~min})$, extension at $72{ }^{\circ} \mathrm{C}(2 \mathrm{~min})$, final extension at $72{ }^{\circ} \mathrm{C}(10$ min) and stored at $4{ }^{\circ} \mathrm{C}$ (Fankem et al. 2006).

Sequencing of targeted fragments of $16 \mathrm{~S} r R N A$ was performed at Gene Analysis unit, Macrogene, Korea using the same primers used for amplification. A near full length of $16 S$ rRNA was sequenced and sequence data were aligned and compared with available published sequences of bacterial lineage at the NCBI GenBank (http://www. ncbi.nlm.nih.gov/) using BLAST. In addition, sequences of previously reported phosphate solubilizing bacteria in earlier studies were downloaded from GeneBank. The sequences were finally aligned in the alignment explorer tool of the MEGA (Molecular Evolutionary Genetic Analysis software) by Tamura (2011) using Clustal-W. The phylogenetic tree was prepared using the Neighbor-Joining method and Kimura- 2 as the model test with a bootstrap value of 1000 pseudoreplicates.

\section{Pot experiment}

The pot experiment was carried out during 1 December 2015-30 June 2016 at Arid Lands Cultivation Research Institute (ALCRI) in the Experimental Farm-City of Scientific Research and Technological Applications (SRTACity) located in Borg Al-Arab City (30 $53^{\prime} 33.17^{\prime \prime} \mathrm{N}$, $29^{\circ} 22^{\prime} 46.43^{\prime \prime}$ E), West Alexandria, Egypt. Calcareous soil sample $(0-30 \mathrm{~cm})$ was collected from (ALCRI) Experimental Farm, air-dried, grinded and passed through a 2-mm sieve. Soil samples analyzed according to the method described by Page et al. (1982) and physical or chemical properties were as follows: $\mathrm{pH}$ 8.39, E.C (filtrate of saturated soil paste) $2.72 \mathrm{dS} \mathrm{m}^{-1}, \mathrm{CaCO}_{3} 31.4 \%$, organic matter $0.97 \%$, total P 4925 ppm, available P 6.12 $\mathrm{ppm}$, total $\mathrm{N} 0.03 \%$, sand $65.3 \%$, silt $16 \%$, clay $18.7 \%$, and soil texture sandy loam. Seeds of (Triticum aestivum L.) variety Gemiza-11 were obtained from Agricultural Research Centre, Egypt. Seeds were surface sterilized by soaking in $70 \%$ ethanol for $3 \mathrm{~min}$ and then in 1\% sodium hypochlorite (bleach) for $10 \mathrm{~min}$. To remove the residual bleach, the seeds were washed ten times with sterile tap water and air-dried before sowing.

\section{Preparation of inoculums and seed sowing}

The three efficient PSB isolates (ENPSB 1, 2, and 3) were grown on nutrient agar, then pure single colonies of each isolate was transferred into $500 \mathrm{ml}$ flasks containing nutrient broth and grown aerobically on a rotating shaker $(150 \mathrm{pm})$ for $48 \mathrm{~h}$ at $30{ }^{\circ} \mathrm{C}$, after that cells were harvested by centrifugation at $3000 \mathrm{rpm}$ for $20 \mathrm{~min}$ and re-suspended in sterile $0.85 \% \mathrm{NaCl}$ solution. The bacterial suspension was then diluted in sterile distilled water to give a final concentration $10^{8} \mathrm{CFU} \mathrm{ml}{ }^{-1}$ (colonyforming unit $\mathrm{CFU}$ ) and used to inoculate wheat grains. For mixed inoculation, an equal volume containing $\left(10^{8}\right.$ $\mathrm{CFU} \mathrm{ml} \mathrm{m}^{-1}$ of each strain) were mixed (1:1:1) and used 
for inoculating wheat seeds. Wheat grains were soaked (except un-inoculated pots) separately with the culture broth of each PSB inoculants for 10 min before sowing. In addition, each plot was inoculated with $1 \mathrm{ml}$ of PSB inoculants containing $10^{8} \mathrm{CFU} \mathrm{ml}{ }^{-1}$ after sowing to ensure soil inoculation. Pots of $17 \mathrm{~cm}$ in diameter and 20 $\mathrm{cm}$ in depth were sterilized with $1.5 \%$ sodium hypochlorite, then sterile water to remove the excess of hypochlorite and filled with $2 \mathrm{~kg}$ calcareous soil. Wheat grains were sown at $1 \mathrm{~cm}$ depth $\left(10\right.$ seeds pot $\left.^{-1}\right)$. Grain germination percent was calculated after 7 days of sowing $(90-100 \%)$ and then were thinned to five seedlings in each pot. Experiment was set up in an open environment covered with wire. Plants were watered weekly to maintain moisture at field capacity.

Recommended doses of $\mathrm{N}$ fertilizer $\left(300 \mathrm{~kg} \mathrm{fed}^{-1}\right.$ of $\mathrm{NH}_{4} \mathrm{NO}_{3} 33.5 \% \mathrm{~N}$ at the rate of $100 \mathrm{~kg} \mathrm{~N} \mathrm{fed}^{-1}$ ) were applied as a main dose in all treatments and added in three equal doses before irrigation. The first dose was added at the time of sowing, the second was applied after 20 days from cultivation and the third one was after 40 days from planting. The recommended dose of $\mathrm{K}$ fertilizer ( $50 \mathrm{~kg} \mathrm{fed}^{-1}$ of potassium sulphate $48 \% \mathrm{~K}_{2} \mathrm{O}$ ) was applied before sowing of grains. Four levels of $\mathrm{P}$ fertilizer were applied as single super phosphate (SSP) $15 \% \mathrm{P}_{2} \mathrm{O}_{5}, \mathrm{P} 100 \%$ of the recommended dose $(150 \mathrm{~kg}$ $\mathrm{fed}^{-1}$ ), P 75\%, P 50\%, and P 0\% (not amended with phosphorus fertilizer) with or without PSB. Phosphorus doses were added and mixed well with soil before sowing.

\section{Experimental design}

The experiment was set in a randomized complete block design (RCBD) with three replicates. To study the effect of inoculation with PSB (ENPSB 1, 2, and 3) as single inoculums or mixed together with the application of phosphors at four levels (SSP 0, 50, 75, and 100 of recommended dosage) as the following T1 (control), T2 (control $+50 \%$ P), T3 (control $+75 \%$ P), T4 (control $+100 \%$ P), T5 (Enterobacter aerogenes $+0 \% \mathrm{P})$, T6 (Enterobacter aerogenes $+50 \% \mathrm{P})$, T7 (Enterobacter aerogenes $+75 \% \mathrm{P})$, T8 (Enterobacter aerogenes $+100 \% \mathrm{P})$, T9 (Enterobacter $\mathrm{sp} .+0 \%$ P), T10 (Enterobacter sp. $+50 \%$ P), T11 (Enterobacter sp. $+75 \%$ P), T12 (Enterobacter sp. + 100\% P), T13 (Pantoea sp. $+0 \%$ P), T14 (Pantoea sp. $+50 \%$ P), T15 (Pantoea sp. $+75 \%$ P), T16 (Pantoea sp. + $100 \%$ P), T17 (mixed culture $(1: 1: 1)+0 \% \mathrm{P})$, T18 (mixed culture $(1: 1: 1)+50 \% \mathrm{P})$, T19 (mixed culture (1:1:1) + 75\% P), and T20 (mixed culture $(1: 1: 1)+100 \% \mathrm{P})$.

\section{Studied parameters}

After 60 days of cultivation, plants were harvested, root and shoot portions of plants were separated, and growth parameters such as shoot height, shoot fresh and dry weight, root fresh, and dry weight. Root length of wheat plants was measured by the line intersects method of (Tennant 1975).

$\mathrm{RL}=(\mathrm{RFW} / 0.1) \times(11 / 14) \times \mathrm{N} \times \mathrm{G}$

Where, RL $=$ root length, $\mathrm{RFW}=$ root fresh weight, $N$ = sum of horizontal and vertical crossing, $G=$ length of the grid unit $(1 \mathrm{~cm})$.

Root radius $\left(r_{0}\right)$ was calculated as follows:

$$
r_{0}=\sqrt{ }\left(\frac{\mathrm{RFW}}{\pi \mathrm{RL}}\right)
$$

Root surface area (SA) was calculated as follows:

$$
S A=2 \pi \times r_{0} \times R L
$$

Plant samples were oven-dried at $70{ }^{\circ} \mathrm{C}$ to a constant weight to determine plant biomass and were finally grinded after drying. Phosphorus concentrations were determined using the vanado-molybdate method (Page et al. 1982). The $\mathrm{P}$ uptake was calculated by multiplying the biomass dry weight with its $\mathrm{P}$ concentration. Rhizosphere of soil samples was collected from each treatment by uprooting the plants carefully without damaging the root system. Roots were shaken gently to remove loosely adhering soil particles from each treatment and then were analyzed for measuring available P content. The soil was extracted by the bicarbonate method and available P by using the molybdate blue color method (Olsen et al. 1954).

\section{Inorganic phosphorous fractionation}

The different fractions of P (Kuo 1996) involved sequential extractions with (i) a solution of $0.1 \mathrm{M}$ in $\mathrm{NaOH}$ and $1 \mathrm{M}$ in $\mathrm{NaCl}$ to remove non-occluded $\mathrm{Al}$ - and Fe-bound $\mathrm{P}$, (ii) $1 \mathrm{M} \mathrm{NaCl}$ and citrate-bicarbonate $(\mathrm{CB})$ to remove $\mathrm{P}$ resorbed during the preceding extraction, (iii) citratedithionite-bicarbonate $(\mathrm{CDB})$ to remove $\mathrm{P}$ occluded within iron oxides, and (iv) $1 \mathrm{M} \mathrm{HCl}$ to remove $\mathrm{Ca}$ bound $\mathrm{P}$. The $\mathrm{P}$ unaccounted for the sum of these forms and organic P consists probably of occluded forms of apatite (Syers et al. 1969). In all extracts, P was analyzed by the method of (Murphy and Riley 1962).

\section{Statistical analysis}

The experiment was arranged in a randomized complete block design (RCBD) with three replicates. Data were analyzed by two-way analysis of variance (ANOVA) at $p$ $\leq 0.05$ using statistical functions of Co-Stat software for statistics (2004). Further, least significant difference (L.S.D 0.05 ) test was used to differentiate between significant and non-significant means.

\section{Results}

Isolation of bacterial isolates

As shown in Table 1, 40 bacterial isolates were isolated from different soil samples using the technique of serial dilution method followed by growing on selective media (NBRIP) and screened for selecting phosphate solubilizing 
Table 1 Quantitative estimation of bacterial isolates for $\mathrm{P}$ solubilization and IAA production

\begin{tabular}{|c|c|c|c|c|}
\hline Isolate no. & $\begin{array}{l}\text { Soluble P } \\
\left(\mathrm{mg} \mathrm{l}^{-1}\right)\end{array}$ & $\begin{array}{l}\text { IAA conc. } \\
\left(\mathrm{mg} \mathrm{I}^{-1}\right)\end{array}$ & Final $\mathrm{pH}$ & $\begin{array}{l}\text { P. S. index } \\
\text { (PSI) }\end{array}$ \\
\hline ENPSB 1 & 707 & 50.5 & 4 & 1.8 \\
\hline ENPSB 2 & 653 & 18.2 & 5.1 & 1.3 \\
\hline ENPSB 3 & 693 & 5.9 & 4 & 2.0 \\
\hline ENPSB 4 & 120 & 41.1 & 4.58 & 2.3 \\
\hline ENPSB 5 & 87 & 39.5 & 4.45 & 1.3 \\
\hline ENPSB 6 & 633 & 34.3 & 4.41 & 2.1 \\
\hline ENPSB 7 & 167 & 32.1 & 5.29 & 1.3 \\
\hline ENPSB 8 & 187 & 31.2 & 4.3 & 1.4 \\
\hline ENPSB 9 & 573 & 30.5 & 4.24 & 1.3 \\
\hline ENPSB 10 & 587 & 30.2 & 4.19 & 1.2 \\
\hline ENPSB 11 & 547 & 25.2 & 5.54 & 2.3 \\
\hline ENPSB 12 & 413 & 20.8 & 4.51 & 1.6 \\
\hline ENPSB 13 & 327 & 19.9 & 4.27 & 1.3 \\
\hline ENPSB 14 & 607 & 19.7 & 4.1 & 1.4 \\
\hline ENPSB 15 & 473 & 19.5 & 4.1 & 2.0 \\
\hline ENPSB 16 & 600 & 18.8 & 4.44 & 1.3 \\
\hline ENPSB 17 & 87 & 47.8 & 5.29 & 1.4 \\
\hline ENPSB 18 & 593 & 17.3 & 6.15 & 1.6 \\
\hline ENPSB 19 & 627 & 16.4 & 4.16 & 1.3 \\
\hline ENPSB 20 & 600 & 12.5 & 4.33 & 2.0 \\
\hline ENPSB 21 & 400 & 10.3 & 4.5 & 1.4 \\
\hline ENPSB 22 & 600 & 10.3 & 4.45 & 1.6 \\
\hline ENPSB 23 & 293 & 8.5 & 3.87 & 1.7 \\
\hline ENPSB 24 & 547 & 7.8 & 4.06 & 1.4 \\
\hline ENPSB 25 & 627 & 5.9 & 3.78 & 2.3 \\
\hline ENPSB 26 & 387 & 43.1 & 4.39 & 1.7 \\
\hline ENPSB 27 & 300 & 3.4 & 4.46 & 1.7 \\
\hline ENPSB 28 & 127 & 2.6 & 4.16 & 1.4 \\
\hline ENPSB 29 & 547 & 1.5 & 3.99 & 1.2 \\
\hline ENPSB 30 & 600 & 0.79 & 4.12 & 1.8 \\
\hline ENPSB 31 & 567 & 0 & 4.2 & 1.6 \\
\hline ENPSB 32 & 40 & 0 & 5.34 & 1.3 \\
\hline ENPSB 33 & 427 & 0 & 4.65 & 1.3 \\
\hline ENPSB 34 & 620 & 0 & 3.93 & 1.5 \\
\hline ENPSB 35 & 113 & 0 & 5.15 & 1.3 \\
\hline ENPSB 36 & 493 & 0 & 4.15 & 1.6 \\
\hline ENPSB 37 & 140 & 0 & 4.88 & 1.2 \\
\hline ENPSB 38 & 193 & 0 & 4.85 & 1.3 \\
\hline ENPSB 39 & 373 & 0 & 4.32 & 1.2 \\
\hline ENPSB 40 & 140 & 0 & 5.31 & 1.4 \\
\hline
\end{tabular}

ENPSB Egyptian native phosphate solubilizing bacteria ability. The phosphate solubilization index (PSI) varied among isolates and ranged from 1.2 to 2.3 on selective broth media. The bacterial colonies showing clear halo zones around the microbial growth were considered as phosphate solubilizers in the presumptive test (Fig. 1). To authenticate the isolation of targeted PSB, which formed clear zone around the colonies, were re-screened to measure the available phosphorus in broth NBRIP medium.

\section{Quantitative estimation of phosphate solubilization}

Ranges of phosphate solubilization by the selected PSB isolates and changes in medium $\mathrm{pH}$ are shown in Table 1 . The soluble P concentration was differed among isolates and ranged between 40 and $707 \mathrm{mg} \mathrm{l}^{-1}$. The solubilization of TCP in the liquid medium by different isolates was accompanied by a significant drop in medium $\mathrm{pH}$ (till 3.78) compared to zero time ( $\mathrm{pH} 7.0)$. The highest amount of solubilization was obtained from the bacterial isolate ENPSB $1\left(707 \mathrm{mg} \mathrm{l}^{-1}\right)$ followed by ENPSB 3 (693.3 $\mathrm{mg} \mathrm{l}^{-1}$ ) with drop in $\mathrm{pH}$ till 4, while isolate ENPSB 2 yielded $\left(653 \mathrm{mg} \mathrm{l}^{-1}\right.$ ) with drop in $\mathrm{pH}$ to 5.1. Generally, there is negative correlation $(r=-0.394$, $p \leq 0.05$ ) between the degree of phosphorus solublilization and the reduction of the medium $\mathrm{pH}$. For measuring phosphorus solubilization kinetics (Fig. 2.), the most efficient phosphate-solubilizing isolates ENPSB 1, ENPSB 2, and ENPSB 3 were allowed to grow for different time intervals in the NBRIP broth medium. Samples were withdrawn periodically every 1 day during the incubation period ( 7 days) and analyzed to estimate available phosphorus in culture supernatant. It was observed that three strains were increased the soluble $\mathrm{P}$ till the sixth day significantly, while after that there was no more increase of available phosphorus.

\section{Estimation of IAA}

Only $75 \%$ of our bacterial isolates were able to produce IAA in nutrient broth medium supplemented with tryptophan. The higher production rate of IAA was obtained in nutrient broth medium inoculated with ENPSB 1 (50.5 $\mu \mathrm{g}$ $\mathrm{ml}^{-1}$ ), while the lower rate was observed with ENPSB 30 $\left(0.79 \mu \mathrm{g} \mathrm{ml}^{-1}\right)$ after $48 \mathrm{~h}$ of incubation (Table 1$)$.

\section{Sequencing of $16 S$ rRNA and phylogenetic analysis}

The identification of PSB strains based on 16S rRNA sequences was presented in Table 2. The partial sequence of targeted part of $16 S$ rRNA was submitted to the Gene bank under Accession nos. KY644046, MF 614152, and KY64 4047 for strains ENPSB 1, 2, and 3 on respectively. The primary comparison of $16 S r R N A$ sequences with reference strains using BLAST indicated that ENPSB 1 showed 95\% similarity with Enterobacter aerogenes strain RB86 (KC431 784), ENPSB 2 gave 94\% similarity with Pantoea sp. strain F30-PCAi-T3P21, and sequence analysis of ENPSB 3 


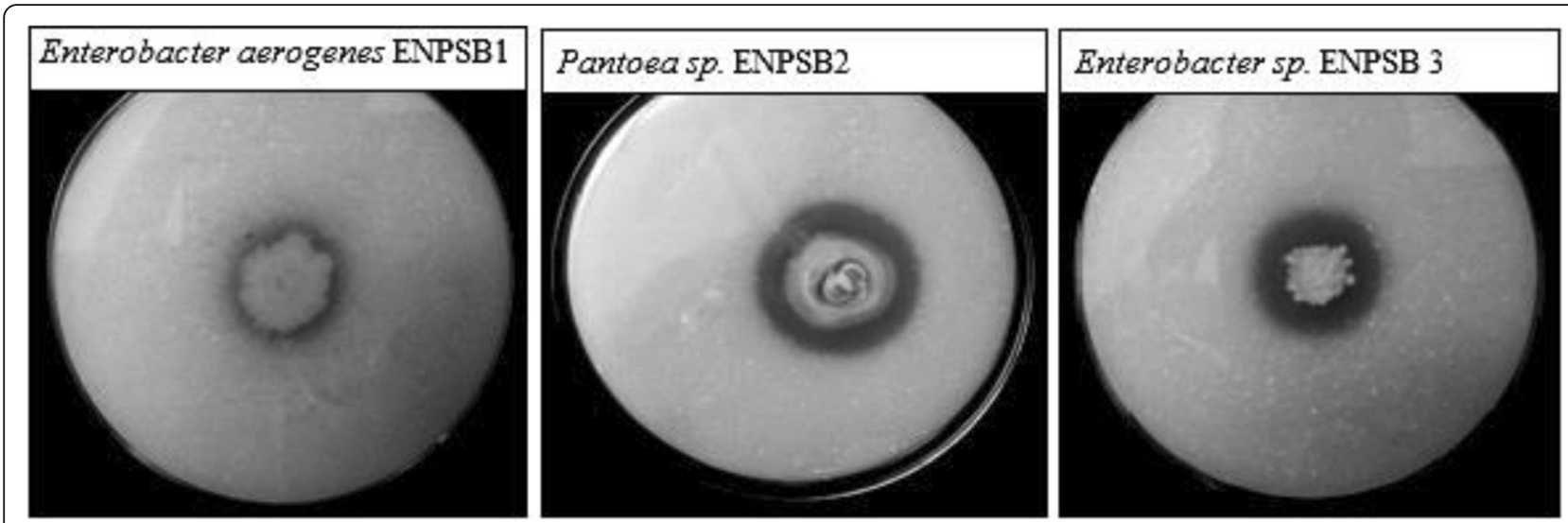

Fig. 1 Bacterial colonies showing clear halo zones around the microbial growth of novel phosphate dissolving bacterial isolates

showed 95\% similarity with Enterobacter sp. (JX067710). The sequence was then aligned by CLUSTAL-W with some $16 S$ rRNA sequences of previously reported phosphate solubilizing bacterial strains belonging to genera $E n$ terobacter, Pantoea, and Burkholderia.

\section{Potted field experiment}

To test the ability of well-selected PSB strains from our preliminary and Laboratory studies, a greenhouse experiment of complete block randomize design was conducted to examine the effect of inoculation with PSB strains (ENPSB 1, 2, and 3) on wheat growth parameters cultivated in calcareous soil samples. Single inoculation of PSB strains ENPSB 1 or 2 or 3 were highly significant increased both fresh and dry weight of shoots as well as phosphorus shoot percent content to control (Table 3).
The optimum level of phosphorus application was 75\% of the recommended dosage with or without inoculation as the maximum level (100\%) was not significant to increase growth parameters compared to other inoculation treatments. The effect of PSB inoculation on soil available phosphorous content is presented in Fig. 3. Likewise, inoculation with mix strains of PSB significantly ( $p$ $\leq 0.05$ ) increased soil available phosphorous compared to uninoculated soil. The interaction effect showed that the maximum interaction effect between PSB and P fertilizer level was obtained by inoculation with mix culture and application of $100 \% \mathrm{P}\left(14.99 \mathrm{mg} \mathrm{kg}^{-1}\right)$, and it was significantly higher than control $+100 \%$ P $(7.75$ $\mathrm{mg} \mathrm{kg}-1$ ) by a rate of $93.4 \%$. However, the consortium inoculation with the three efficient strains gave high available phosphorus in soil by a rate of $46.5 \%$ than the control.

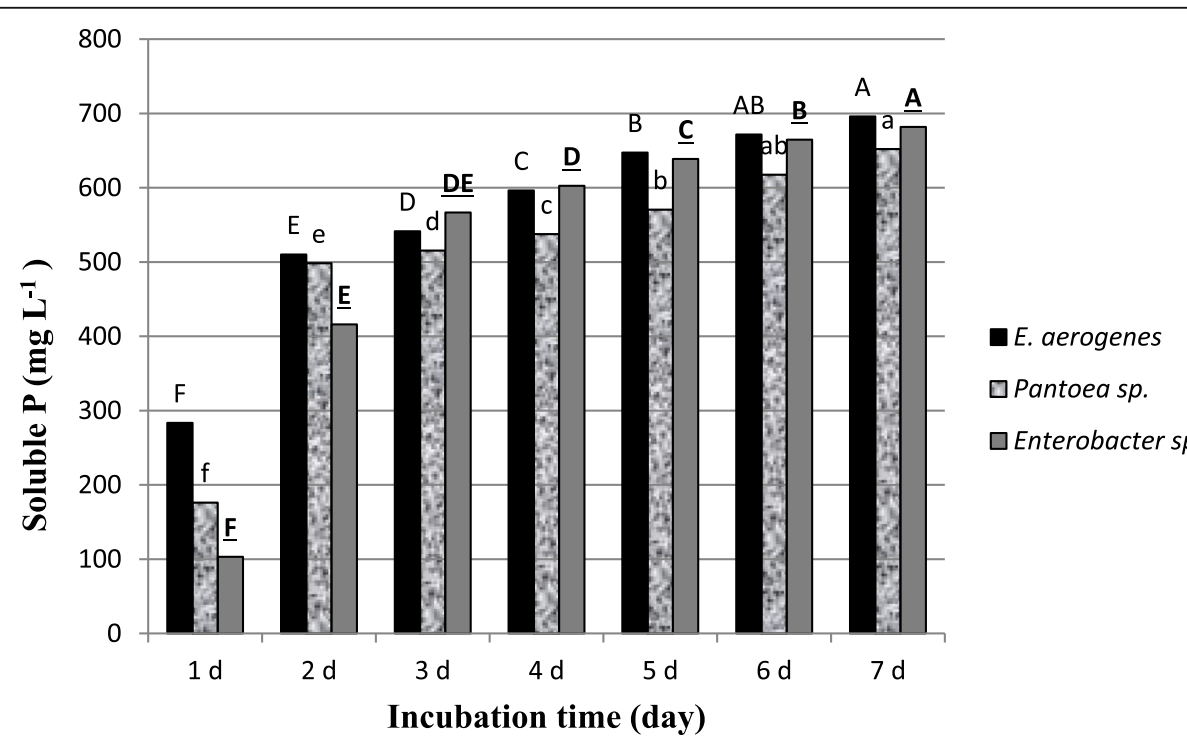

Fig. 2 The effect of incubation time on P solubilization rates on NBRIP media. Columns marked with the same alphabetical letter(s) within comparable means in the same isolate's column do not differ significantly using the revised L.S.D. test at 0.05 levels 
Table 2 Similarity of 165 rRNA sequences for the selected strains compared to those obtained from database

\begin{tabular}{lllllll}
\hline Isolates code & Nucleotide length & Max. score & Total score & E value & Query coverage (\%) & Identification \\
\hline ENPSB 1 & $1460 \mathrm{bp}$ & 2150 & 2150 & 0.0 & 97 & $95 \%$ Enterobacter aerogenes strain RB86 \\
ENPSB 2 & $1402 \mathrm{bp}$ & 769 & 769 & 0.0 & 100 & $94 \%$ Pantoea sp. strain F30-PCAi-T3P21 \\
ENPSB 3 & $1420 \mathrm{bp}$ & 2204 & 2204 & 0.0 & 97 & $95 \%$ Enteriobacter sp. \\
\hline
\end{tabular}

The mix culture gave significant results compared to control and this may be due to synergistic effect of multiple PGPR strains. As shown in Table 4, mix bacterial inoculation and $\mathrm{P}$ application (75\% of recommended dosage) was reported to support the far distribution of roots to longdistance in the soil (root length 4604.3 and $4105.3 \mathrm{~cm}$ ) and occupied a big surface area (root surface area 258.8 and $235.3 \mathrm{~cm} 2$ ) which reflected positively on root $\mathrm{P}$ content (0.165 and 0.139) compared to other treatments.

\section{Effect of PSB and P fertilizer application on the in-organic $P$ fractions}

All $\mathrm{P}$ forms such as phosphorus bound with $\mathrm{Ca}, \mathrm{Fe}$, and $\mathrm{Al}$ were estimated to examine the direct effect of both PSB and P fertilizers on releasing or availability of $\mathrm{P}$ in such alkaline soil. The Ca-bound $\mathrm{P}$ was the largest P fraction ranged from $118.2-208.5 \mathrm{mg} / \mathrm{kg}$ soil supplementary Additional file 1: Table S1. The $\mathrm{CaCO}_{3}-\mathrm{P}$, the non-occluded $\mathrm{Al}$ and $\mathrm{Fe}-\mathrm{P}$, and the occluded $\mathrm{P}$ were very small fractions. Thus, result is compatible with the high concentration of $\mathrm{CaCO} 3$ (31.4\%) in the soil used (Additional file 1: Table S1). The calcareous nature of these soils tended to promote the sequestration of $\mathrm{P}$ into the Ca-bound rather than the $\mathrm{Fe}-\mathrm{Al}$-bound fraction. In the present study, non-occluded $\mathrm{Al}$ and $\mathrm{Fe}, \mathrm{CaCO}_{3}$ and occluded Fe-P concentrations in soil were higher with PSB application compared to the control. On the other hand, Ca-

Table 3 Interaction effect (bacterial strain $\times$ phosphorus fertilizer \%) on shoot growth

\begin{tabular}{|c|c|c|c|c|c|}
\hline & Treatment & Shoot height $(\mathrm{cm})$ & Shoot fresh weight (g) & Shoot dry weight (g) & Shoot P (\%) \\
\hline$\overline{\mathrm{T} 1}$ & Control (not inoculated $+0 \% \mathrm{P}$ ) & 36.6 & 1.93 & 0.38 & 0.140 \\
\hline $\mathrm{T} 2$ & Control $+50 \% \mathrm{P}$ & 43.6 & 3.25 & 0.63 & 0.176 \\
\hline T3 & Control $+75 \% \mathrm{P}$ & 48.0 & 4.12 & 0.78 & 0.231 \\
\hline T4 & Control $+100 \% P$ & 47.7 & 3.98 & 0.75 & 0.240 \\
\hline T5 & E. aerogenes $+0 \% \mathrm{P}$ & 45.4 & 4.15 & 0.86 & 0.197 \\
\hline T6 & E. aerogenes $+50 \% \mathrm{P}$ & 47.9 & 4.81 & 1.00 & 0.219 \\
\hline $\mathrm{T7}$ & E. aerogenes $+75 \% \mathrm{P}$ & 53.7 & 5.76 & 1.19 & 0.253 \\
\hline T8 & E. aerogenes $+100 \% \mathrm{P}$ & 51.6 & 4.83 & 1.12 & 0.255 \\
\hline T9 & Enterobacter sp. $+0 \% \mathrm{P}$ & 43.6 & 3.25 & 0.72 & 0.191 \\
\hline T10 & Enterobacter sp. $+50 \% \mathrm{P}$ & 47.9 & 3.98 & 0.76 & 0.195 \\
\hline T11 & Enterobacter sp. $+75 \% \mathrm{P}$ & 48.2 & 4.35 & 0.94 & 0.229 \\
\hline $\mathrm{T} 12$ & Enterobacter. sp. $+100 \% \mathrm{P}$ & 48.8 & 5.07 & 1.13 & 0.224 \\
\hline $\mathrm{T} 13$ & Isolate B $+0 \% P$ & 42.0 & 3.62 & 0.71 & 0.161 \\
\hline T14 & Isolate B + $50 \% \mathrm{P}$ & 47.2 & 4.36 & 0.78 & 0.239 \\
\hline T15 & Isolate B + 75\% P & 54.9 & 4.14 & 0.86 & 0.228 \\
\hline T16 & Isolate B + 100\% P & 52.7 & 4.35 & 0.86 & 0.238 \\
\hline T17 & Mixed culture $(1: 1: 1)+0 \% P$ & 47.4 & 4.69 & 0.94 & 0.196 \\
\hline $\mathrm{T} 18$ & Mixed culture $(1: 1: 1)+50 \% P$ & 50.9 & 5.23 & 1.08 & 0.219 \\
\hline T19 & Mixed culture $(1: 1: 1)+75 \% P$ & 50.3 & 6.38 & 1.32 & 0.267 \\
\hline T20 & Mixed culture $(1: 1: 1)+100 \% \mathrm{P}$ & 53.9 & 5.47 & 1.22 & 0.269 \\
\hline L.S.D (5\%) & & 5.4 & 0.998 & 0.194 & 0.035 \\
\hline
\end{tabular}




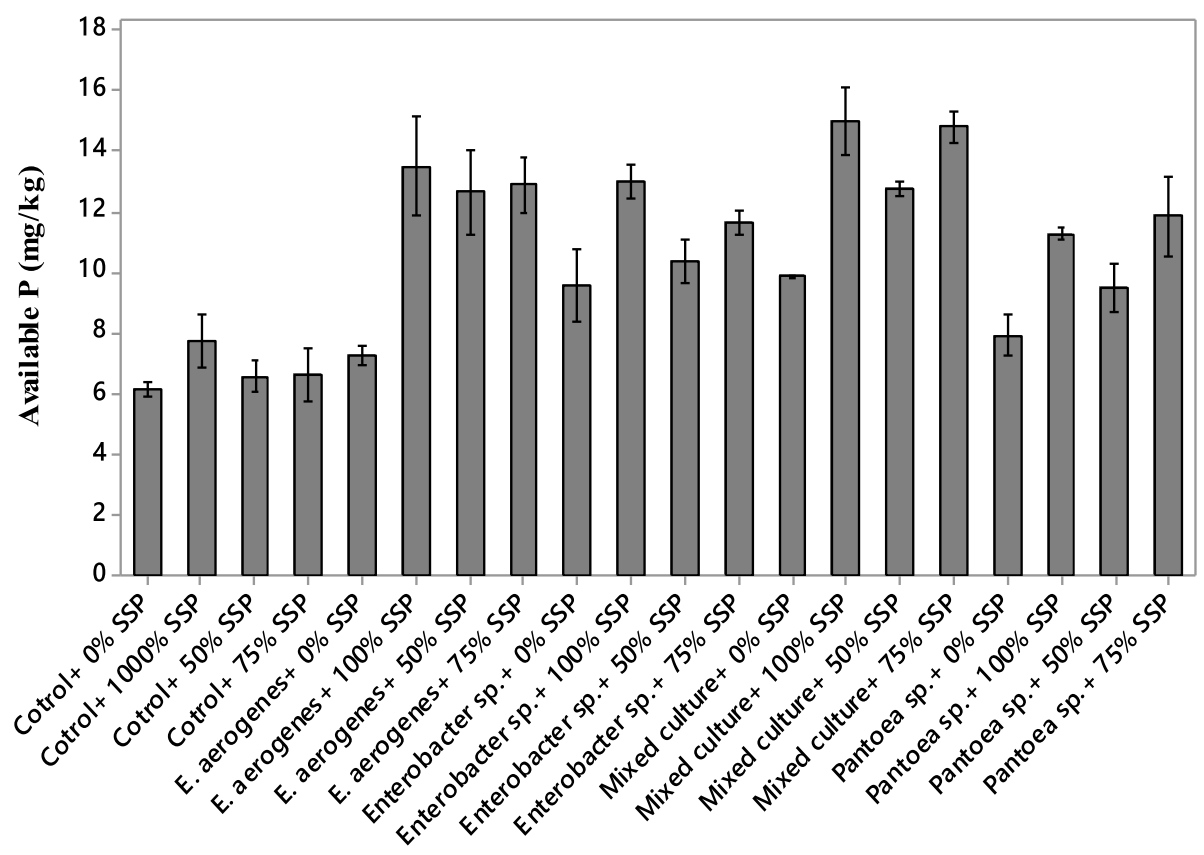

Treatments

Fig. 3 Interaction effect between bacterial isolate and phosphorus fertilizer \% on available phosphorus in the soil

Table 4 Interaction effect (bacterial strain $\times$ phosphorus fertilizer \%) on root growth parameters

\begin{tabular}{|c|c|c|c|c|c|c|}
\hline Treatments & Root fresh weight (g) & Root dry weight (g) & Root length $(\mathrm{cm})$ & Root radius $(\mathrm{cm})$ & Root surface area $\left(\mathrm{cm}^{2}\right)$ & Shoot P (\%) \\
\hline $\mathrm{T} 1$ & 0.28 & 0.090 & 1594.6 & 0.0075 & 75.0 & 0.059 \\
\hline $\mathrm{T} 2$ & 0.61 & 0.128 & 2612.3 & 0.0087 & 141.9 & 0.069 \\
\hline T3 & 0.62 & 0.149 & 2784.2 & 0.0084 & 146.8 & 0.108 \\
\hline T4 & 0.64 & 0.151 & 1846.3 & 0.0104 & 121.3 & 0.109 \\
\hline T5 & 0.72 & 0.146 & 2882.1 & 0.0092 & 161.2 & 0.090 \\
\hline T6 & 0.76 & 0.160 & 3739.9 & 0.0081 & 189.1 & 0.094 \\
\hline $\mathrm{T7}$ & 0.97 & 0.179 & 3877.0 & 0.0089 & 217.4 & 0.140 \\
\hline T8 & 0.89 & 0.164 & 3084.7 & 0.0097 & 185.5 & 0.142 \\
\hline T9 & 0.57 & 0.128 & 2416.6 & 0.0087 & 131.0 & 0.069 \\
\hline $\mathrm{T} 10$ & 0.60 & 0.130 & 2885.1 & 0.0080 & 146.6 & 0.108 \\
\hline T11 & 0.73 & 0.154 & 3012.1 & 0.0088 & 165.9 & 0.117 \\
\hline $\mathrm{T} 12$ & 0.76 & 0.147 & 2862.2 & 0.0091 & 164.5 & 0.148 \\
\hline $\mathrm{T} 13$ & 0.71 & 0.135 & 2165.7 & 0.0103 & 138.9 & 0.081 \\
\hline T14 & 0.72 & 0.135 & 3153.7 & 0.0087 & 169.0 & 0.125 \\
\hline T15 & 0.93 & 0.167 & 3171.9 & 0.0096 & 192.3 & 0.141 \\
\hline T16 & 0.74 & 0.146 & 2630.0 & 0.0095 & 156.5 & 0.147 \\
\hline T17 & 0.79 & 0.157 & 2759.9 & 0.0096 & 165.0 & 0.113 \\
\hline T18 & 0.80 & 0.162 & 3882.2 & 0.0081 & 197.2 & 0.122 \\
\hline T19 & 1.16 & 0.229 & 4604.3 & 0.0090 & 258.8 & 0.165 \\
\hline T20 & 1.08 & 0.209 & 4105.3 & 0.0093 & 235.3 & 0.139 \\
\hline L.S.D (5\%) & 0.235 & 0.037 & 1139.8 & 0.0011 & 54.8 & 0.033 \\
\hline
\end{tabular}


bound P concentrations in PSB application treatments were lower than those in control treatments.

\section{Discussion}

Generally, $20-80 \%$ of soil phosphorus is inorganic form (Richardson 2001) and plants have hard difficulties to absorb phosphorus directly from the soil (Greiner and Alminger 2001); therefore, it is necessary to find another possible and safe solution to support plants with phosphorus in alkaline soils instead of synthetic fertilizers which it is highly expensive for small farmers and it has negative effect on the environment. The ability of specific kinds of bacteria such as PSB to convert insoluble forms of phosphorus to an available form is an important tool for increasing plant yields especially in the highly alkaline soils (Shi et al. (2017).

Therefore, PSB is well an alternative strategy for solving such a problem which it can be used to increase available plant phosphate levels particularly in soils with high pH (Goldstein 1986). In such calcareous soil of Northwestern coast of Egypt, where phosphorus is fixed as tri-calcium phosphate, and which it is deemed to be a poor fertile soil due to the low availability of phosphorus and other elements, the phosphate solubilizing bacteria (PSB) strategy is completely required. Similarly, Abou El-Seoud and Abdel-Megeed (2012) reported that PSB increased $\mathrm{P}$ availability and uptake, and the plant growth (shoots and roots) of maize plants grown in P limited soils. Consequently, we directed our efforts to isolate a group of PSB strains which can be used as a biofertilizer to increase phosphorus availability in such deteriorated soils. Forty bacterial isolates which gave a hallo zone around colonies growing on NBRIP selective medium as previously reported by Gaur (1990) in the primary test were selected to confirm their useful role for releasing the $\mathrm{P}$ amount in the broth medium and examined their biological contribution to improve and develop the growth of Wheat plants in such soils.

Many different kinds of soil microorganisms are able to dissolve rock phosphates in a liquid culture (Goenadi et al. 2000; Vazquez et al. 2000). Several studies have been reported that $\mathrm{P}$ solubilizing activity is always associated with a drop in the medium $\mathrm{pH}$ (Nautiyal et al. 2000; Pradhan and Sukla 2005; Achal et al. 2007); however, some other reports do not note such effect (Kucey et al. 1989). Our results are in agreement with those obtained by Nautiyal et al. (2000) and by Pradhan and Sukla (2005) as the medium $\mathrm{pH}$ reduced after inoculation with native phosphate dissolving strains ENPSB 1, 2 , and 3 due to produce organic acids. The reduction of $\mathrm{pH}$ was attributed to the varying diffusion rates of different organic acids secreted by the tested organisms. The solubilization of insoluble phosphates depends on different factors including a decrease in $\mathrm{pH}$, microorganisms and the insoluble phosphate used (Nahas 1996; Nautiyal et al. 2000; Kang et al. 2002). The raising of P concentration in the medium containing phosphate solubilizing microorganism may be related to the secretion of organic acid metabolite types, which should correlate with the $\mathrm{pH}$ of the medium (Narsian et al. 1995). However, they failed to establish a clear cut relationship between phosphate solubilization and culture $\mathrm{pH}$. In the same line, Mahfouz and Sharf-Eldin (2007) reported that using of biofertilization on Egyptian soils has reduced the soil $\mathrm{pH}$, which led to increased nutrient availability and plant growth.

Our results indicated that the three efficient strains ENPSB 1, 2, and 3 were increased significantly the soluble $\mathrm{P}$ till the sixth day, while after that there was no more significant increase of available phosphorus due to consuming the amount of phosphorus or the depletion of nutrients in the culture, especially carbon source that it is essential for the production of organic acids (Kang et al. 2002; Kim and Lei 2005; Chaiharn M, Lumyong 2009), also availability of soluble phosphorus in the culture medium may act as an inhibitory effect on further phosphate solubilization and excretory toxic products may responsible for such decline in P-solubilization (Varsha-Narsian et al. 1994). Beside the ability of these PSB strains ENPSB 1, 2, and 3 to convert the unavailable phosphorus to available form, they produced IAA hormone. Production of the auxin indoleacetic acid (IAA) is widespread among plant-associated bacteria. Many researchers have also reported the microbial biosynthesis of plant hormones associated with the ability of solubilization of insoluble phosphates by microorganisms (Fallo et al. 2015; Zahir et al. 2004).

Molecular identification of well-selected and high efficient PSB strains based on the sequencing of $16 S$ rRNA and phylogenetic affiliation confirmed that the three PSB strains ENPSB 1, 2 and 3 belonged to the same family of Enterobactericiae (Fig. 4). Isolation of bacterial strains of this family have already been obtained from various soils and found to have inorganic phosphate (IP) solubilizing abilities (Vassilev et al. 1999; Chung et al. 2005; Shoebitz et al. 2009; Frank and Julius 2012). Two of the high efficient strains (ENPSB 1 and 2) were identified as Enterobacter and these results are in the same line with those obtained by Liu et al. (2014) who found that strain of Enterobacter cloacae have the ability to solubilize unavailable forms of phosphorus. In addition, Taha et al. (1969) observed that Enterobacter sp. was known to resist dryness conditions similar to the conditions where our strains were isolated from (Northwestern Coast of Egypt). Dominance of Enterobacter strains in the calcareous soils indicating that this family of bacteria is common and has unique capabilities for releasing phosphorus in such deteriorated soils which can help to 


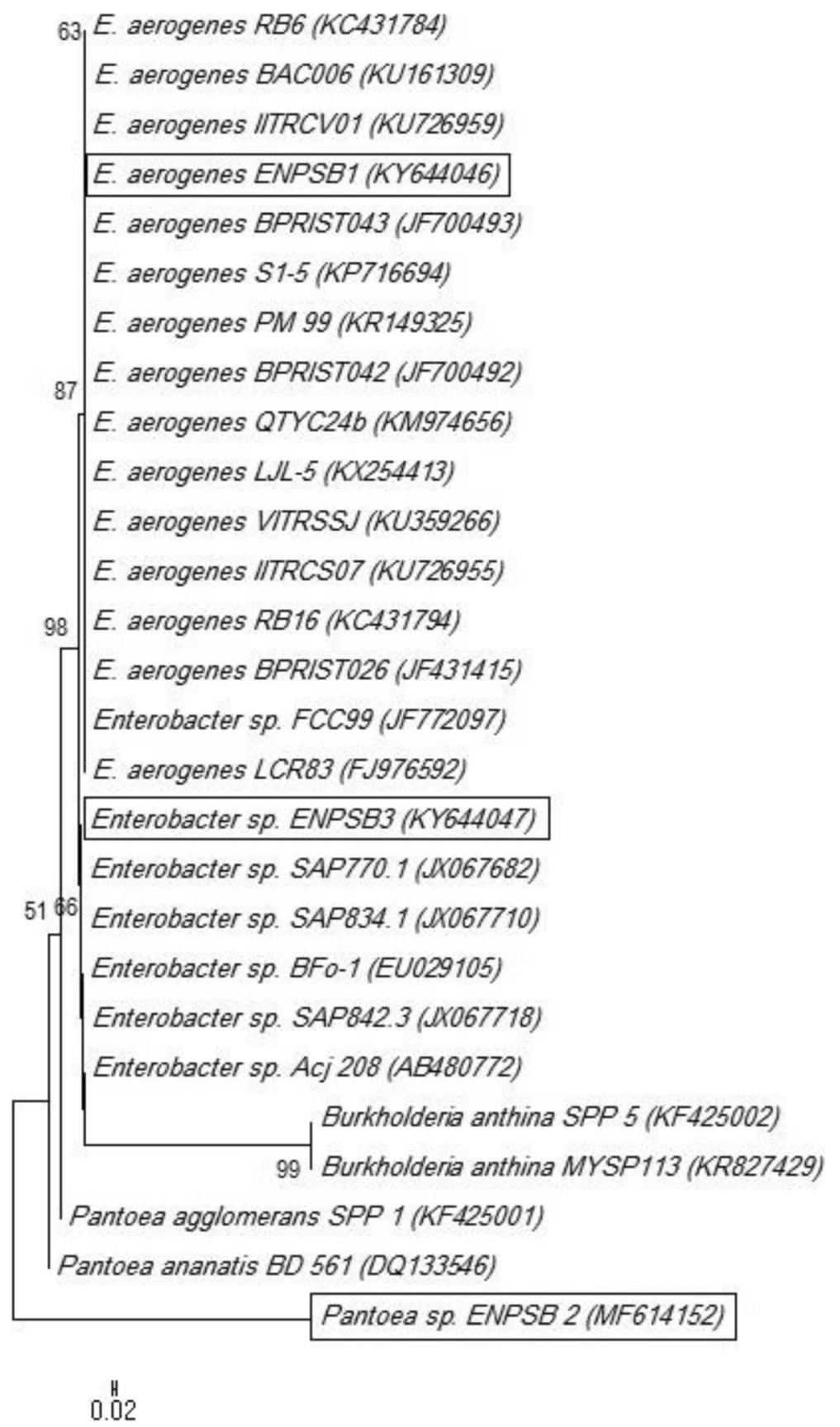

Fig. 4 Phylogenetic tree of three representative phosphate dissoloving bacterial strains and their genetic affiliation compared with standard strains based on partial 165 rRNA sequence analysis (the Egyptian native strains are put inside the square)

solve the problems of phosphorus fertilization in a big sector of low soil productivity due to the alkalinity. Our results indicated also that strain ENPSB 1 identified as Enterobacter aerogenes and this consistent with similar findings by Park et al. (2016) who confirmed the ability of this species to play an interesting role for phosphate solubilizing. Strain ENPSB 3 identified as Pantoea sp. and such a result similar to those obtained by $\mathrm{Li}$ et al. (2008) who reported that this species has the ability of phosphate solubilizing. In the same time, MagallonServin (2014) identified three strains of Pantoea agglomerans as phosphate dissolving bacteria.

Single inoculation of PSB strains ENPSB 1, 2, and 3 were highly significant to increase shoot fresh and dry weights and phosphorus shoot content compared to control (Table 3); these results are inconsistent with those obtained by Krasilnikov (1961); and by Lifshitz et al. (1987) who reported that the use of PSB strains 
could enhance the growth of Maize and Wheat. On the other side, the use of plant growth-promoting rhizobacteria (PGPR), such as (PSB) biofertilizer, was a well sustainable solution to improve plant growth (Ekin 2010).

Our results prevailed that the mix culture of PSB strains ENPSB 1, 2, and 3 gave significant results compared to control, and this may be due to synergistic effect of multiple PGPR strains (Upadhyay et al. 2012; Combes-Meynet et al. 2011). The positive effects of PSB strains ENPSB 1, 2, and 3 on shoots, root growth, and phosphorus uptake of wheat plants, because these strains may serve as PGPR (Kumar et al. 2014), or increase the available phosphorus (Sundara et al. 2002; Liu et al. 2014) and production of IAA (Hayat et al. 2010; Selvakumar et al. 2011). Some of our strains had the dual biological function of PSB and IAA production. Raising the $P$ content of wheat plants in our results due to single or mix inoculation with PSB strains were similar to (Sundara et al. 2002) who found that the application of PSB of Bacillus megaterium var. phosphaticum strains was associated with an increase in the $\mathrm{P}$ availability in the soil. Similar results were obtained by Abou-El Seoud and Abdel-Megeed (2012) who found that the available phosphorus was increased by about $65 \%$ in maize plants inoculated with PSB compared to un-inoculated. Unambiguously, our results indicated that the inoculation with single or mix culture of PSP strains (ENPSB) were contributed to increase the amount of available phosphorus in the soil and this is well in agreement with results obtained by Liu et al. (2014) who found that the highest level of available $\mathrm{P}$ and the greatest stimulation of plant height and dry weight were obtained in soils coinoculated with the three bacterial strains of phosphate dissolving bacteria. Shi et al. (2017) and Adnan et al. (2017) reported that the use of PSB strains increased P availability and reduced the negative effect of calcification on the soil.

Results suggested that PSB strains played a significant role in increasing phosphorus fixed with $\mathrm{Ca}, \mathrm{Al}$, and $\mathrm{Fe}$ concentrations but decreasing Ca-bound $\mathrm{P}$ in calcareous soil, suggesting that the activities of PSB strains inhibited the transformation of soil P towards Ca-P (Zhou et al. 2005).

Correlation coefficients between different $\mathrm{P}$ fractions and available $\mathrm{P}$ (Additional file 1: Table S2) indicated that the available $\mathrm{P}(\mathrm{Pa})$ has a significant and positive correlation with non-occluded $\mathrm{Al}$ and $\mathrm{Fe}-\mathrm{P}, \mathrm{CaCO}_{3}-\mathrm{P}$, and occluded Fe-P but has a significant negative correlation with Ca-bounded $\mathrm{P}$. This indicated that a large part of unavailable phosphorus in this soil was fixed as apatite (Zhou et al. 2005). A significant correlation between various fractions of $\mathrm{P}$ with available $\mathrm{P}$ was indicating for a possible contribution of all $\mathrm{P}$ fractions to the available $\mathrm{P}$ pool in soil. A significant correlation was also observed between P forms themselves, which is presumably a reflection of the existence of a dynamic relation between the chemical forms of phosphorus in the soil (Adhami et al. 2007). Linear regression of concentration of each $\mathrm{P}$ fraction, $(Y)$ as a function of SSP levels added to soil $(X)$ is presented in Additional file 1: Table S3. Phosphorus concentrations in Pi fractions amended with SSP were linearly and significantly at $(p<0.01)$ and were correlated with the cumulative additions of P from SSP fertilizer. The slope of each equation reflected the increase in the soil $\mathrm{P}$ fraction with each increment of $\mathrm{P}$ added by the SSP fertilizer.

\section{Conclusion}

The isolation of 40 bacterial strains from the rhizosphere of cultivated wheat plants in Delta region and Northwestern coast of Egypt proved their ability to solubilize tricalcium phosphate and gave attention to the role of PSB strains ENPSB 1, 2, and 3 as biofertilizer with dual biological function for releasing the available phosphorus and producing IAA with the ultimate goal to increase the growth of Wheat plants in the highly alkaline soils, and such highly effective PSB strains can be used in the field to solve the problem of phosphorus deficiency in a big sector of such poor soils after confirmed their capabilities for releasing phosphorus from insoluble forms.

\section{Supplementary information}

Supplementary information accompanies this paper at https://doi.org/10. 1186/s42269-019-0212-9.

Additional file 1: Table S1. Effect of SSP \%, PSB and their interaction on in-organic P fractions. Table S2. Simple correlation coefficients ( $r$ ) between soil available $P$ and $P$ fractions. Table $\mathbf{S 3}$. Linear regression of concentration of each $P$ fraction, $(Y$ ) as a function of SSP added to soil.

\section{Abbreviations}

PSB: Phosphate solubilizing bacterial; NBRIP: National Botanical Research Institute's phosphate growth medium; ENPSB: Egyptian Native Phosphate Solubilizing Bacteria; IAA: Indole acetic acid; PSM: Phosphate solubilizing microorganisms; PGPR: Plant growth-promoting rhizobacteria; SDS: Sodium dodicyl sulphate; DNA: Deoxyribonucleic acid; rRNA: Ribosomal ribonucleic acid; PCR: Polymerase chain reaction; CFU: Colony-forming unit; SSP: Single super phosphate; RCBD: Randomized complete block design; CDB: Citratedithionite-bicarbonate; ANOVA: analysis of variance; PSI: Phosphate solubilization index

\section{Acknowledgements}

Authors are grateful to the Genetic Engineering and Biotechnology Research Institute (GEBRI) and the Arid Land Cultivation Research Institute (ALCRI) at the City of Scientific Research and the Technology Application (SRTA-City), to cover the costs of carrying out this research work. This is in cooperation and guidance of the Soil and Agricultural Chemistry Department, Faculty of Agriculture, Saba-Basha, Alexandria University.

\section{Authors' contributions}

All authors contribute to the conception, design of the work; the acquisition, analysis, interpretation of data; the creation of new software used in the work and have drafted the work or substantively revised it. All authors have approved the submitted version (and any substantially modified version that involves the author's contribution to the study). All authors have agreed to 
be personally accountable for the author's own contributions and to ensure that questions related to the accuracy or integrity of any part of the work, even ones in which the author was not personally involved, are appropriately investigated, resolved and the resolution documented in the literature. All authors read and approved the final manuscript.

\section{Funding}

The funding resources mainly come through the contribution of the Land and Water Technologies Department, Arid Land Cultivation Research Institute (ALCRI), and the Environmental Biotechnology Department, Genetic Engineering and Biotechnology Research Institute (GEBRI) at City of Scientific Research and Technology Application (SRTA-City), Borg El-Arab, Alexandria, Egypt. This is in cooperation of the Soil and Agricultural Chemistry Dept., Faculty of Agriculture, Saba-Basha, Alexandria University, Alexandria, Egypt

\section{Availability of data and materials}

The datasets used and/or analyzed during the current study are available from the corresponding author on reasonable request. All figures, maps, and tables generated during this study are included in this published article

\section{Ethics approval and consent to participate}

Not applicable.

\section{Consent for publication}

Not applicable.

\section{Competing interests}

The authors declare that they have no competing interests.

\section{Author details}

'Land and Water Technologies Department, Arid Lands Cultivation Research Institute (ALCRI), City of Scientific Research and Technological Applications (SRTA-City), Borg El-Arab, Alexandria, Egypt. ${ }^{2}$ Soil and Agricultural Chemistry Department, Faculty of Agriculture, Saba-Basha, Alexandria University, Alexandria, Egypt. ${ }^{3}$ Environmental Biotechnology Department, Genetic Engineering and Biotechnology Research Institute (GEBRI), City of Scientific Research and Technological Applications (SRTA-City), Borg El-Arab, Alexandria, Egypt.

\section{Received: 8 June 2019 Accepted: 15 October 2019} Published online: 27 December 2019

\section{References}

Abou-El-Seoud I, Abdel-Megeed A (2012) Impact of rock materials and biofertilizations on $\mathrm{P}$ and $\mathrm{K}$ availability for maize (Zea maize) under calcareous soil conditions. Saudi J Biol Sci. 19:55-63

Achal V, Savant W, Reddy MS (2007) Phosphate solubilization by a wild type strain and UV-induced mutants of Aspergillus tubingensis. Soil Biol Biochem. 39:695-699

Adhami E, Memarian HR, Rassaei F, Mahdavi E, Maftoun M, Ronaghi A, Fasaei RG (2007) Relationship between phosphorus fractions and properties of highly calcareous soils. Aust J Soil Res. 45:255-261

Adnan M, Shah Z, Fahad S, Arif M, Alam M, Khan IA, Mian IA, Basir A, Ullah H, Arshad M, Rahman I, Saud S, Ihsan MZ, Jamal Y (2017) Amanullah. Hammad HM, Nasim W. Phosphate-solubilizing bacteria nullify the antagonistic effect of soil calcification on bioavailability of Phosphorus in alkaline soils. Scientific Rep www.nature.com/scientificreports/www.nature.com/scientificreports/ww. nature.com/scieifi/

Bhattacharyya PN, Jha DK (2012) Plant growth-promoting rhizobacteria (PGPR): emergence in agriculture. World J Microbiol Biotechnol. 28:1327-1350

Brick JM, Bostock RM, Silversone SE (1991) Rapid in situ assay for indole acetic acid production by bacteria immobilized on nitrocellulose membrane. Appl Environ Microbiol. 57:535-538

Chaiharn M, Lumyong S (2009) Phosphate solubilization potential and stress tolerance of rhizobacteria from rice soil in Nothern Thailand. World J Microbiol Biotechnol. 25:305-314

Chung H, Park M, Madhaiyan M, Seshadri S, Song J, Cho H, Sa T (2005) Isolation and characterization of phosphate solubilizing bacteria from the rhizosphere of crop plants of Korea. Soil Biol Biochem. 37:1970-1974

Combes-Meynet E, Pothier JF, Moënne-Loccoz Y, Prigent-Combaret C (2011) The Pseudomonas secondary metabolite 2, 4-diacetylphloroglucinol is a signal inducing rhizoplane expression of Azospirillum genes involved in plantgrowth promotion. Mol Plant-Microbe Interact. 24:271-284

Datta M, Banish S, Dupta RK (1982) Studies on the efficacy of a phytohormone producing phosphate solubilizing Bacillus firmus in augmenting paddy yield in acid soils of Nagaland. Plant Soil. 69:365-373

Ekin Z (2010) Performance of phosphate solubilizing bacteria for improving growth and yield of sunflower (Helianthus annuus L.) in the presence of phosphorus fertilizer. Afr J Biotech. 9:3794-3800

Fallo G, Mubarik NR (2015) Triadiati. Potency of Auxin producing and phosphate solubilizing bacteria from dryland in Rice Paddy field. Res J Microbiol. 10(6): 246-259

Fankem H, Nwaga D, Deubel A, Dieng L (2006) Occurrence and functioning of phosphate solubilizing microorganisms from oil palm tree (Elaeis guineensis) rhizosphere in Cameroon. Afr J Biotechnol. 5:2450-2460

Frank O, Julius O (2012) Some characteristics of a plant growth promoting Enterobacter sp. isolated from the roots of maize. Adv Microbiol. 2:368-374

Gaur AC (1990) Phosphate solubilizing microorganisms as biofertilizers. Omega Scientific Publishers, New Delhi, India

Gaur AC, Ostwal KP (1972) Influence of phosphate dissolving Bacilli on yield and phosphate uptake of wheat crop. Indian J Exp Biol. 10:393-394

Glick B. Plant growth-promoting bacteria: Mechanisms and applications. Scientifica Article ID 963401: 2012.

Goenadi D, Siswanto H, Sugiarto Y (2000) Bioactivation of poorly soluble phosphate rocks with a phosphorus-solubilizing fungus. Soil Sci Soci America J. 64:927-932

Goldstein AH (1986) Bacterial solubilization of mineral phosphates: historical perspectives and future prospects. Am J Altern Agric. 1:57-65

Greiner R, Alminger LM (2001) Stereo specificity of myoinositol hexakis phosphate dephosphorylation by phytate degrading enzymes of cereals. J Food Biochem. 25:229-248

Hayat R, Ali S, Amara U, Khalid R, Ahmed I (2010) Soil beneficial bacteria and their role in plant growth promotion: a review. Annal Microbiol. 60:579-598

Kang SC, Hat CG, Lee TG, Maheshwari DK (2002) Solubilization of insoluble inorganic phosphates by a soil-inhabiting fungus Fomitopsis sp. PS 102. Curr Sci. 82:439-442

Khan MS, Zaidi A, Wani PA (2007) Role of phosphate solubilizing microorganisms in sustainable agriculture. A review. Agronomy for Sustainable Development, Springer Verlag. Germany 27:29-43

Kim T, Lei XG (2005) An improved method for a rapid determination of phytase activity in animal feed. J. Anim. Science. 83:1062-1067

Krasilnikov M (1961) On the role of soil bacteria in plant nutrition. J Gen Appl Microbiol. 7:128-144

Kucey RMN, Janzen HH, Legget ME (1989) Microbial mediated increases in plant available phosphorus. Adv Agron. 42:199-228

Kumar A, Maurya B, Raghuwanshi R (2014) Isolation and characterization of PGPR and their effect on growth, yield and nutrient content in wheat (Triticum aestivum L.). Biocat Agri Biotechnol. 3:121-128

Kuo S (1996) Phosphorus in: Bartels, JM, Bigham JM (eds), Methods of Soil Analysis 3, Chemical Methods. Soil Science Society of America, Madison, Wl: 869-919

Leonard G, Mark D, James F. Basic Methods in Molecular Biology. Elsevier. Co. Inc. Avenue, New Yok. USA: 1986.

Li JH, Wang ET, Chen WF, Chen WX (2008) Genetic diversity and potential for promotion of plant growth detected in nodule endophytic bacteria of soybean grown in Heilongjiang province of China. Soil Biol Bichem. 40:238-246

Lifshitz R, Kloepper JW, Kozlowski M, Simonson C (1987) Growth promotion of canola (rapeseed) seedlings by a strain of Psedomonas putida under genotobiotic conditions. Can J Microbiol. 33:390-395

Liu FP, Liu HQ, Zhou HL, Dong ZG, Bai XH, Bai P, Qiao JJ (2014) Isolation and characterization of phosphate-solubilizing bacteria from betel nut (Areca catechu) and their effects on plant growth and phosphorus mobilization in tropical soils. Biol Fert Soils. 50:927-937

Magallon-Servin P (2014) Development of an inoculant of phosphate rocksolubilizing bacteria to improve Maize growth and nutrition. Ph. D. Thesis. University of Laval, Quebec, Canada

Mahfouz SA, Sharaf-Eldin MA (2007) Effect of mineral vs. biofertilizer on growth, yield, and essential oil content of fennel (Foeniculum vulgare Mill.). Int Agrophy. 21:361-366

Mehnaz S, Lazarovits G (2006) Inoculation effects of Pseudomonas putida, Gluconacetobacter azotocaptans, and Azospirillum lipoferum on corn plant growth under greenhouse conditions. Micro Ecol. 51:326-335 
Murphy J, Riley JP (1962) A modified single solution method for the deterimination of phosphate in natural waters. Ana Chimica Acta. 27:31-36

Murty MG, Ladha JK (1988) Influence of Azospirillum inoculation on the mineral uptake and growth of rice under hydroponic conditions. Plant Soil. 108:281-285

Nahas E (1996) Factors determining rock phosphate solubilization by microorganism isolated from soil. World J Microbiol Biotechnol. 12:18-23

Narsian V, Thakkar J, Putei HH (1995) Mineral phosphate solubilization by Aspergillus aculeatus. Indian J Exp Biol. 33:91-93

Narula N, Kumar V, Behl RK, Duebel AA (2000) Effect of P solubilizing Azotobacter chroococcum on $\mathrm{N}, \mathrm{P}, \mathrm{K}$ uptake in $\mathrm{P}$ responsive wheat genotypes grown under green house conditions. J Plant Nutr Soil Sci. 163:393-398

Nautiyal CS (1999) An efficient microbiological growth medium for screening phosphate solubilizing microorganisms. FEMS Microbiol Lett. 182:265-270

Nautiyal CS, Bhadauria S, Kumar P, Lal H (2000) Stress induced phosphate solubilization in bacteria isolated from alkaline soils. FEMS Microbiol Lett. 182: 291-296

Olsen SR, Cole CV, Watanabe FS, Dean LA. Estimation of available phosphorus in soils by extraction with sodium bicarbonate. Circular 939. United States Department of Agriculture, Washington, DC: 1954; 171-179.

Page AL, Miller RH, Keeney DR, Baker DE. In Methods of Soil Analysis, Part 2. Chemical and Microbiological Properties, Agron. Monograph no. 9 (2nd Edition). ASA-SSSA, Madison, WI, USA: 1982

Park JH, Lee HH, Han CH, Yoo JA, Yoon MH (2016) Synergistic effect of coinoculation with phosphate solubilizing bacteria. Korean J Agric Science. 43 400-414

Pradhan N, Sukla LB (2005) Solubilization of inorganic phosphate by fungi isolated from agriculture soil. African J Biotechnol. 5:850-854

Premono ME, Moawad AM, Vleck PLG (1996) Effect of phosphate solubilizing Pseudmonas putida on the growth of maize and its survival in the rhizosphere. Indonasian J Crop Sci. 11:13-23

Richardson AE (1994) Soil microorganisms and phosphorus availability. In: Pankhurst CE, Doube BM, Grupta WSR, Grace PR (eds) Soil Biota, Management in Sustainable Farming Systems. CSIRO, Melbourne, Australia, pp 50-62

Richardson AE (2001) Prospects for using soil microorganisms to improve the acquisition of phosphorus by plants. Aust J Plant Physiol. 28:897-906

Selvakumar G, Joshi P, Suyal P, Mishra PK, Joshi GK, Bisht JK (2011) Pseudomonas lurida M2RH3 (MTCC 9245), a psychrotolerant bacterium from the Uttarakhand Himalayas, solubilizes phosphate and promotes wheat seedling growth. World J Microbiol Biotechnol. 27:1129-1135

Setiawati A, Handayanto E. Role of phosphate solubilizing bacteria on availability phosphorus in Oxisols and tracing of phosphate in corn by using ${ }^{32} \mathrm{P}$. In: $19^{\text {th }}$ World Congress of Soil Science, Soil Solutions for a Changing World, Brisbane, Australia: 2010.

Shi XK, Ma JJ, Lui LJ (2017) Effects of phosphate solubilizing bacteria application on soil phosphorus availability in coal mining subsidence area in Shanxi. J Plant Interact. 12:137-142

Shoebitz M, Ribaudo CM, Pardo MA, Cantore LL, Ciampi L, Cura JA (2009) Plant growth promoting properties of a strain of Enterobacter ludwigii isolated from Lolium perenne rhizosphere. Soil Biol Biochem. 41:1768-1774

Sudhakar P, Chattopadhyay GN, Gangwar SK, Ghosh JK (2000) Effect of foliar application of Azotobacter, Azospirillum and Beijerinckia on leaf yield and quality of mulberry (Morus alba). J Agric Sci. 134:227-234

Sundara B, Natarajan V, Hari K (2002) Influence of phosphorus solubilizing bacteria on the changes in soil available phosphorus and sugarcane and sugar yields. Field Crop Res. 77:43-49

Syers JK, Shah R, Walker TW (1969) Fractionation of phosphorus in two alluvial soils and particle size separates. Soil Science. 108:283-289

Taha SM, Mahmoud SAZ (1969) Damaty A, Halim E, El hafez AMA. Activity of phosphate dissolving bacteria in Egyptian soils. Plant Soil. 31:149-160

Tamura K, Peterson D, Peterson N, Stecher G (2011) MEGA5: molecular evolutionary genetics analysis using maximum likelihood, evolutionary distance and maximum parsimony methods. Mol Biol Evol. 28:2731-2739

Tennant D (1975) A test of a modified line intersect method of estimating root length. J Ecol. 63:995-1001

Toro M. Phosphate solubilizing microorganisms in the rhizosphere of native plants from tropical savannas: An adaptive strategy to acid soils? In: Velaquez, C., Rodriguez-Barrueco, E. (eds.) Developments in Plant and Soil Sciences. Springer, the Netherlands: 2007; 249-252.
Upadhyay SK, Singh JS, Saxena AK, Singh DP (2012) Impact of PGPR inoculation on growth and antioxidant status of wheat under saline conditions. Plant Biol. 14:605-611

Varsha-Narsian J, Thakkar J, Patel HH (1994) Inorganic phosphate solubilization by some yeast. Indian J Microbiol. 35:113-118

Vassilev N, Toro M, Vassileva M, Azcon R, Barea JM (1999) Rock phosphate solubilization by immobilized cells of Enterobacter sp. in fermentation and soil conditions. Bioresour Technol. 61:29-32

Vazquez P, Holguin G, Puente M, Cortes AE (2000) Phosphate solubilizing microorganisms associated with the rhizosphere of mangroves in a semi arid coastal lagoon. Biol Fertil Soils. 30:460-468

Weisburg WG, Barns SM, Pelletier DA, Lane DJ (1991) 16 S ribosomal DNA amplification for phylogenetic study. J Bacteriol. 173:697-703

Zahir ZA, Arshad M, Frankenberger WT Jr (2004) Plant growth promoting rhizobacteria: perspectives and application in agriculture. Adv Agron. 81:96168

Zhou XB, Hong JP, Xie YH (2005) Effects of phosphorous bacteria fertilizer on phosphorus validity of calcareous soil. J Soil Water Conserv. 19:70-73

\section{Publisher's Note}

Springer Nature remains neutral with regard to jurisdictional claims in published maps and institutional affiliations.

\section{Submit your manuscript to a SpringerOpen ${ }^{\circ}$ journal and benefit from:}

- Convenient online submission

- Rigorous peer review

- Open access: articles freely available online

- High visibility within the field

- Retaining the copyright to your article

Submit your next manuscript at $\boldsymbol{\nabla}$ springeropen.com 